\title{
The Treasury Securities Market: Overview and Recent Developments
}

Dominique Dupont and Brian Sack, of the Board's Division of Monetary Affairs, prepared this article. Emilie Archambeault provided research assistance.

The market for U.S. Treasury securities is by many measures the largest, most active debt market in the world. At the end of September 1999, the amount of Treasury debt held outside federal government accounts totaled about $\$ 3.6$ trillion, close to the amount of outstanding debt securities issued by all U.S. corporations combined. ${ }^{1}$ Moreover, enormous amounts of Treasury securities are traded every business day. Over the first nine months of 1999, the primary dealers in government securities, which are among the most active participants in the market, together executed an average of $\$ 190$ billion worth of transactions in the securities each day. ${ }^{2}$

The heavy trading is an indication of the pivotal role of U.S. Treasury securities in world financial markets. Investors of many types-commercial banks, investment banks, money market funds, insurance companies, individual investors, and foreign central banks, among others - use the Treasury market for investing and hedging purposes. Yields on the securities are widely viewed as benchmarks in the pricing of other debt securities and are analyzed for the information they might reveal about market participants' expectations about the future path of the economy and monetary policy.

This article begins with a description of the structure of the Treasury market, including the process by which securities are issued in the primary market and the mechanics of the secondary market. The determinants of investor demand for Treasury securities are then discussed in some detail. The article concludes with a discussion of several recent developments and emergent trends that have affected the market, including the advent of inflation-indexed securities, a reduction in the issuance of Treasury securities, and shifts

1. Corporate debt securities include corporate bonds and commercial paper outstanding and exclude debt and mortgage-backed securities issued by federal agencies and government-sponsored enterprises.

2. Source: Federal Reserve Bank of New York. toward electronic trading and alternative clearing arrangements.

\section{OVERVIEW OF THE MARKET}

The market for U.S. Treasury securities has a complex structure and involves numerous participantsthe Department of the Treasury, the Federal Reserve System, government securities dealers and brokers, and other holders of Treasury securities.

\section{Scope of the Market}

The federal government finances its expenditures in excess of tax receipts through the sale of debt obligations. Over the years, the Congress has delegated to the Department of the Treasury its authority under the Constitution to issue debt securities. The United States, initially as the Continental Congress, first incurred debt in 1776 when it borrowed funds to finance the Revolutionary War. ${ }^{3}$ Total Treasury debt remained fairly small in the first half of the nineteenth century but rose sharply with the Civil War and again with World War I (chart 1). After declining slightly, the debt increased nearly threefold during the Great Depression and exploded in the 1940s as the government financed expenditures related to World War II. From its postwar low in 1949, outstanding Treasury debt grew gradually for nearly two decades before accelerating at the time of the Vietnam War and during the subsequent period of high inflation. In the 1980s, the growth of the stock of debt picked up further, spurred by the tax cuts and rapid increases in defense spending of the decade.

In recent years, budget surpluses have halted the upward climb in the total amount of Treasury debt held outside government accounts. However, the overall magnitude of outstanding debt remains substantial, a legacy of past budget deficits. At the end of

3. Rafael A. Bayley, The National Loans of the United States of America from July 4, 1776 to June 30, 1880, as Prepared for the Tenth Census of the United States (Washington, DC: U.S. Government Printing Office, 1883). 
1. Total outstanding Treasury debt, 1851-1999

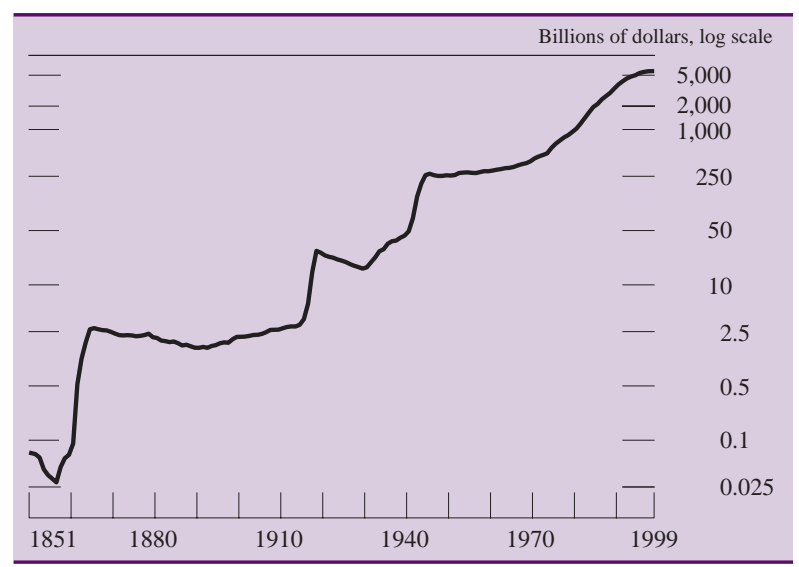

Note. Data for 1999 are through the second quarter. SourCE. U.S. Department of the Treasury.

September 1999, the total par value of outstanding Treasury debt, including that held in government accounts, stood at about $\$ 5.6$ trillion, or about 61 percent of the total annual output of the economy. This fraction, though considerable, is well below the peak after World War II (chart 2).

\section{Types of Treasury Securities}

Of the \$5.6 trillion in outstanding debt at the end of September 1999, about $\$ 3.2$ trillion was in the form of marketable securities-instruments that may be traded after their initial purchase. These securities are the focus of this article. New marketable securities are regularly offered in maturities ranging from thirteen weeks to thirty years. Bills-securities having a

2. Ratio of total outstanding Treasury debt to gross domestic product, 1930-99

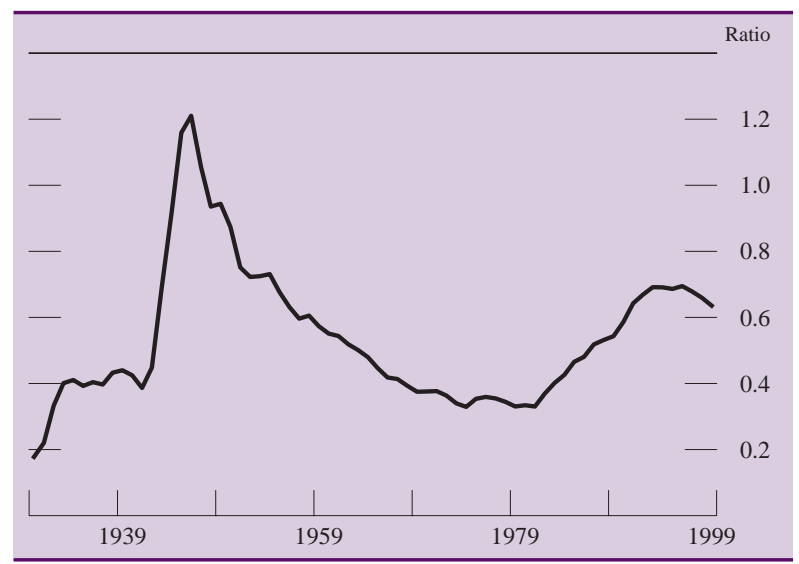

NoTE. Data for 1999 are through the second quarter.

SourCE. U.S. Department of the Treasury; U.S. Department of Commerce. maturity of one year or less-sell at a discount from their face value (par) and do not pay interest before maturity. Investors realize a return on bills from the increase in their price to face value at maturity. Notes-securities having an initial maturity of one to ten years-and bonds-securities having an initial maturity of more than ten years-offer investors semiannual interest payments, or coupons.

More than half the marketable Treasury debt outstanding is in the form of notes, while bills and bonds each represent about 20 percent (chart 3). Some of the outstanding bonds are callable securities, which may be redeemed by the Treasury before their maturity; however, only noncallable securities have been issued since 1985. Most of the marketable debt outstanding (about 97 percent) is in the form of nominal securities-securities for which the coupon and principal payments are fixed in dollar terms. Since 1997, the Treasury has also issued securities whose coupon and principal payments are indexed to the rate of inflation. (The indexed-securities program is described later in the section "Availability of a New Instrument.")

The Treasury also issues a considerable amount of nonmarketable securities, which, in contrast to marketable securities, may not be traded after their initial purchase. Nonmarketable debt is primarily in the form of Government Account Series (83 percent), State and Local Government Series (7 percent), and savings bonds (7 percent). Government Account Series securities are held mainly by off-budget government programs, such as social security, which by law must invest accumulated surpluses in nonmarket-

3. Distribution of marketable Treasury debt outstanding, by type of security, September 30, 1999

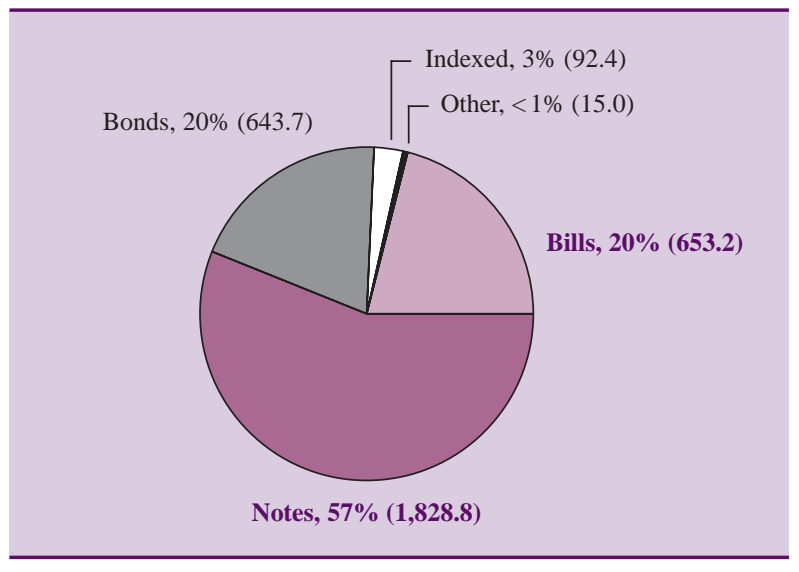

Note. Numbers in parentheses are amounts outstanding, in billions of dollars.

Source. Monthly Statement of the Public Debt of the United States (U.S. Department of the Treasury), September 1999. 
able Treasury securities. State and Local Government Series (SLGS) securities are Treasury securities offered to those governments as a result of 1969 federal legislation restricting them from investing proceeds from tax-exempt bonds in higher-yielding investments; yields on SLGS securities are set on a case-by-case basis to make it possible for the purchaser to comply with that legislation, although the yields must be at least 5 basis points below the yields on marketable Treasury securities having comparable maturities. Savings bonds, which are issued in small denominations, are redeemable at any time after a short initial holding period. In addition to offering small investors an instrument for saving, some savings bond series have special characteristics such as indexation to the rate of inflation and special tax exemptions on interest payments used to pay for qualified higher education expenses.

\section{Issuance of Treasury Securities: The Primary Market}

Marketable Treasury securities are issued through regularly scheduled auctions in what is called the primary market. The process importantly involves the Federal Reserve Banks, which serve as conduits for the auctions. ${ }^{4}$ Because market activity is concentrated in New York, the Federal Reserve Bank of New York coordinates much of the auction activity.

\section{Primary Dealers}

Approximately 2,000 securities brokers and dealers are registered to operate in the government securities market. ${ }^{5}$ Although all these firms may bid at Treasury auctions, participation is typically concentrated among a small number of these firms, the primary dealers. Primary dealers are selected by the Federal

4. This is one of several ways in which the Reserve Banks act as fiscal agents of the Treasury, as permitted by the Federal Reserve Act. Other fiscal agency services provided to the Treasury are detailed in Gerald D. Manypenny and Michael L. Bermudez, "The Federal Reserve Banks as Fiscal Agents and Depositories of the United States," Federal Reserve Bulletin, vol. 78 (October 1992), pp. 727-37.

5. These firms are registered with the Securities and Exchange Commission, as required by the Government Securities Act of 1986 , which establishes a comprehensive legal framework regulating all government securities brokers and dealers so as to ensure the integrity of the government securities market. The legislation focuses on the capitalization of brokers and dealers and grants the Treasury authority to develop and implement rules regarding transactions of government securities. The enforcement of these rules is delegated to existing regulatory agencies and self-regulatory organizations.
Reserve Bank of New York as counterparties for open market operations (government securities transactions related to the Federal Reserve's implementation of monetary policy). They are required to participate meaningfully in both open market operations and Treasury auctions and to provide policy-relevant market information to the New York Reserve Bank. Along with the consolidation of the financial industry has come a decline in the number of primary dealers, from a peak of forty-six in 1988 to thirty as of October 1999.

\section{Auctions}

To foster liquidity in the market, the Treasury issues securities consistently and predictably through a regular schedule of auctions. The process begins several days before the scheduled auction when the Treasury announces the details of the upcoming issue, including the amount to be auctioned and the maturity date. After the auction is announced but before it takes place, investors begin trading the yet-to-be-issued security in what is called the whenissued market. Transactions in this market are agreements to exchange securities and funds on the day the new security is issued (although a considerable portion of when-issued positions are unwound before the issue date). The when-issued market allows new Treasury issues to be efficiently distributed to investors and provides useful information to potential bidders about the prices the Treasury may receive at the upcoming auction.

On the day of the auction, bids may be submitted to a Federal Reserve Bank or Branch or to the Treasury's Bureau of the Public Debt. Although all entities may submit bids for their own accounts, depository institutions and registered government securities brokers and dealers may also bid on behalf of their customers. Many of these bids are entered through TAAPS (Treasury Automated Auction Processing System), an automated system for processing auction bids that was implemented in the early 1990s.

Two types of bids may be submitted at the auction. Competitive bids specify both the quantity of the security sought and a yield. ${ }^{6}$ If the specified yield is within the range accepted at the auction, the bidder is awarded the entire quantity sought (unless the specified yield is the highest rate accepted, in which case the bidder is awarded a prorated portion of the bid,

6. At bill auctions, the bidder specifies a discount rate, described below, rather than a yield. 
as described below). Noncompetitive bids, which typically account for a small proportion of auction amounts in part because of restrictions on their size, do not specify a yield; instead, bidders agree to accept the yield determined at the auction and in return are guaranteed the amount of the security sought.

In most auctions, noncompetitive bids must be submitted by noon and competitive bids by 1:00 p.m. (all times are local New York time, unless stated otherwise). To determine the range of yields to be accepted, the quantities specified in all noncompetitive bids are summed and that total is subtracted from the total offered. Competitive bids are then accepted in ascending order in terms of their yields until the quantity of accepted bids reaches the quantity offered. Bids at the highest accepted yield, referred to as the stop-out yield, are prorated so that the total amount of bids accepted equals the total amount offered. The results of the auction are typically announced by 1:30 p.m.

Since November 1998, all Treasury securities have been auctioned according to the uniform-price method. ${ }^{7}$ Each successful competitive bidder and each noncompetitive bidder is awarded securities at the price corresponding to the stop-out yield. Previously, most securities had been issued according to the multiple-price method, meaning that securities were awarded at prices corresponding to the yield of each successful competitive bid. In such auctions, bidders must be concerned with the "winner's curse" - the tendency for a successful bidder to pay a price higher than the value assessed by other auction participants. ${ }^{8}$ By mitigating the winner's curse, the uniform-price auction may elicit more aggressive bids, possibly increasing the Treasury's revenue.

As of the end of September 1999, nominal Treasury securities were offered under the following schedule: $\$ 6.5$ billion of thirteen-week bills and $\$ 7.5$ billion of twenty-six-week bills auctioned weekly; $\$ 10$ billion of fifty-two-week bills every four weeks; $\$ 15$ billion of two-year notes monthly; $\$ 15$ billion of five-year notes and $\$ 12$ billion of ten-year notes quarterly; and $\$ 10$ billion of thirtyyear bonds semiannually. ${ }^{9}$ The auctions of five-, ten-,

7. Before that time, the Treasury conducted uniform-price auctions for some of its issues, including two- and five-year notes. See box "Regulatory Reforms."

8. Vincent Reinhart, "An Analysis of Potential Treasury Auction Techniques," Federal Reserve Bulletin, vol. 78 (June 1992), pp. 403-13.

9. These totals do not reflect quantities allocated to the Federal Reserve or to foreign official institutions. and thirty-year nominal securities are held around the middle of the quarter and are referred to as "midquarter refundings." Inflation-indexed notes and bonds are also brought to market quarterly. In addition to these regularly scheduled issues, the Treasury occasionally offers cash management bills-securities having very short maturities issued to bridge temporary funding needs. The borrowing cost for cash management bills has tended to be a bit higher than that for regularly issued instruments. ${ }^{10}$

Instead of issuing a new security, the Treasury may add to, or reopen, an existing issue, allowing it to increase the outstanding amount of the issue. Securities with larger amounts outstanding tend to be more liquid, making them more attractive to investors. The Treasury systematically reopens Treasury bills: Every fourth twenty-six-week bill is a reopening of a fiftytwo-week bill (which is as often as possible given the auction schedule), every thirteen-week bill is a reopening of a twenty-six-week bill, and some cash management bills are reopenings of other bills. In contrast, the Treasury has only infrequently reopened notes and bonds; since 1990, about 20 percent of the auctions of ten-year notes and thirty-year bonds have been reopenings. The infrequency of reopenings of notes and bonds may be due partly to an obstacle presented by the Internal Revenue Service's Original Issue Discount (OID) rule, which prevents the Treasury from reopening an issue trading at a price discount equal to or greater than 0.25 percent of par value per full year of remaining maturity. ${ }^{11}$ On November 3, 1999, the Treasury issued a temporary rule allowing it to reopen securities within one year of issuance regardless of the size of the discount.

The Treasury has adjusted the auction schedule over time in keeping with its changing financing needs (table 1). It has stopped issuing securities at those maturities it judged to be less popular with investors, preferring to concentrate issuance in fewer maturities in order to preserve the sizes of those issues. In particular, it canceled the twenty-year bond in 1986, the four-year note in 1990, the seven-year note in 1993, and the three-year note in 1998. It also recently reduced the frequency of issuance of the five-year note from monthly to quarterly and the frequency of issuance of the thirty-year bond from three times to twice a year by eliminating the November auction. The Treasury has discussed possible

10. David Simon, "Segmentation in the Treasury Market: Evidence from Cash Management Bills," Journal of Financial and Quantitative Analysis, vol. 26 (March 1991), pp. 97-108.

11. The OID rule does not apply if the Treasury declares an acute, protracted shortage in a security. See box "Regulatory Reforms." 
1. Frequency of auctions of Treasury securities, by maturity, 1985-99

\begin{tabular}{|c|c|c|c|c|c|c|c|c|c|c|c|}
\hline \multirow{2}{*}{ Year } & \multicolumn{11}{|c|}{ Type of security } \\
\hline & 13-week & 26-week & 52-week & 2-year & 3-year & 4-year & 5-year & 7-year & 10-year & 20-year & 30-year \\
\hline $\begin{array}{l}1985 . \\
1986 . \\
1987 . \\
1988 . \\
1989 . \\
1990 . \\
1991 . \\
1992 . \\
1993 . \\
1994 . \\
1995 . \\
1996 . \\
1997 . \\
1998 . \\
1999 .\end{array}$ & Weekly & Weekly & $\begin{array}{l}\text { Every 4th } \\
\text { week }\end{array}$ & Monthly & \begin{tabular}{|} 
Quarterly \\
$\mid$ \\
None \\
$(5 / 15 / 98)$
\end{tabular} & $\begin{array}{c}\text { Quarterly } \\
\text { None } \\
(12 / 31 / 90) \\
\mid\end{array}$ & $\begin{array}{l}\text { Quarterly } \\
\text { Monthly } \\
(1 / 31 / 91)\end{array}$ & Quarterly & $\begin{array}{c}\text { Quarterly } \\
\text { 6x/yr (7/15/96) } \\
\text { Quarterly } \\
\text { (8/15/97) }\end{array}$ & $\begin{array}{c}\text { Quarterly } \\
\text { None } \\
(1 / 15 / 86) \\
\mid\end{array}$ & Quarterly \\
\hline
\end{tabular}

Note. Date indicates when a security was first issued under a new schedule or, if discontinued, when a security was last issued.

SOURCE. Treasury Bulletin.

1. In August 1999, the Treasury announced that it would discontinue the November auction and issue 30-year bonds in February and August only.

future cutbacks in the issuance of one-year bills and two-year notes as well.

Changes in the auction schedule have naturally affected the maturity of outstanding Treasury debt. The average maturity of marketable debt has varied considerably over the past three decades (chart 4). More recently, the maturity peaked at about six years at the beginning of the 1990s, after which the Treasury began to shorten the maturity in an attempt to reduce its borrowing costs. Over the past several years, the maturity has again begun to rise as a result of a reduction in the issuance of securities having shorter maturities (discussed in the section "Reduction in the Supply of Nominal Treasury Debt"). The elimination of the November thirty-year bond auction may help counter this rise.

4. Average maturity of marketable Treasury debt, 1964-99

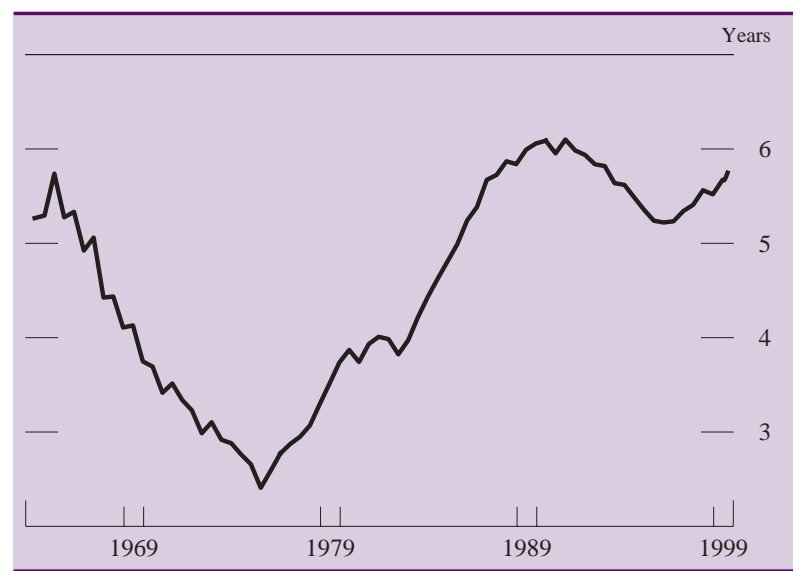

Note. Excludes inflation-indexed securities and holdings of the Federal Reserve. Data for 1999 are through September.

SourCE. U.S. Department of the Treasury.
Trading in Treasury Securities: The Secondary Market

The market for government securities is an over-thecounter market in which participants trade with one another on a bilateral basis rather than on an organized exchange. (Treasury securities are officially registered at the New York Stock Exchange, but trading in that market is negligible.) Trading activity takes place between primary dealers, non-primary dealers, and customers of these dealers, including financial institutions, nonfinancial institutions, and individuals.

Many dealers, particularly the primary dealers, "make markets" in Treasury securities by standing ready to buy and sell securities at specified prices. In the process of making markets, dealers purchase securities at the bid price and sell the same securities at a slightly higher price, the offer price. Through these sales and purchases, the dealer can facilitate transactions between customers while taking only temporary positions in the security. In doing so, the dealer earns the difference between the bid and offer prices, referred to as the bid-offer spread.

In addition to transacting directly with customers, primary dealers frequently trade with one another. The majority of transactions between primary dealers and other large market participants take place through the six interdealer brokers. These brokers provide the dealers with electronic screens that display the best bid and offer prices among the dealers. Dealers can execute trades through an interdealer broker-either "hitting" a bid price or "taking" an offer price_for a small fee. In this structure, the interdealer brokers provide two important services: They disseminate price and trade information efficiently and provide anonymity to market participants. 
2. Daily trading volume in Treasury securities, 1999:Q2

\begin{tabular}{r|c|c}
\hline \multicolumn{1}{c|}{ Type of security } & $\begin{array}{c}\text { Average among all } \\
\text { primary dealers } \\
\text { (millions of dollars) }\end{array}$ & $\begin{array}{c}\text { Percentage among } \\
\text { most active } \\
\text { primary dealers }\end{array}$ \\
\hline Bills $\ldots \ldots \ldots \ldots \ldots \ldots \ldots \ldots$ & 29,451 & 44 \\
Coupon securities $\ldots \ldots \ldots \ldots \ldots$ & 162,614 & 52 \\
Indexed securities $\ldots \ldots \ldots \ldots \ldots$ & 1,282 & 74 \\
Total $\ldots \ldots \ldots \ldots \ldots \ldots \ldots$ & 193,347 & 51 \\
\hline
\end{tabular}

NotE. The most active primary dealers are the six with the highest volume of transactions in each type of security during the quarter.

Source. Federal Reserve Bank of New York.

The thirty primary dealers are among the most active participants in the secondary market. In the second quarter of 1999, they engaged in an average of $\$ 193$ billion in transactions in Treasury securities each day (table 2) - about $\$ 105$ billion with other dealers through interdealer brokers and the other $\$ 88$ billion either with customers or directly with other dealers. ${ }^{12}$ This activity is fairly concentrated: The six primary dealers with the highest volume of transactions in Treasury securities accounted for about 50 percent of the primary dealers' trading activity.

Treasury securities can be traded almost around the clock (about twenty-two hours a day). Trading begins in Tokyo at 7:30 p.m. (New York time) and continues until 3:00 a.m., when it passes to the London market. ${ }^{13}$ Trading in London continues until 7:30 a.m., at which time it begins in New York, where it continues until 5:30 p.m. Although market activity is worldwide, about 94 percent of the trading volume transacted through interdealer brokers takes place during New York trading hours, leaving about 4 percent and 2 percent of volume during London and Tokyo hours respectively. ${ }^{14}$ Moreover, according to market participants, a significant portion of overseas trading occurs at times when trading operations are being shifted from one market to another. ${ }^{15}$ Overseas markets for

12. In comparing these figures, note that dealer-to-dealer transactions are counted twice.

13. To be precise, because Japan has not adopted daylight saving time, the market opens in Tokyo at 7:30 p.m. eastern daylight time or 6:30 p.m. eastern standard time.

14. Michael J. Fleming, "The Round-the-Clock Market for U.S. Treasury Securities," Federal Reserve Bank of New York, Economic Policy Review, vol. 3 (July 1997), pp. 9-32. This analysis is based on 1994 data; preliminary analysis by the author using 1998 data does not suggest significant changes in the patterns of overseas trading of Treasury securities.

15. Brian Madigan, and Jeff Stehm, "An Overview of the Secondary Market for U.S. Treasury Securities in London and Tokyo," Finance and Economics Discussion Series 94-17 (Board of Governors of the Federal Reserve System, Divisions of Research and Statistics and Monetary Affairs, July 1994).
Treasury securities appear to be less liquid than U.S. markets; dealers reportedly post wider bid-offer spreads and stand ready to buy or sell smaller amounts of securities at the posted prices. ${ }^{16}$ The final exchange of securities for cash (settlement) typically occurs in New York, regardless of where the transaction originated.

\section{Quoting Conventions}

Treasury coupon securities are quoted in terms of their price, expressed in dollars. The quoted price of a coupon security is the "clean price," which excludes accrued interest. When a transaction takes place, the purchaser must pay the seller the clean price plus the accrued interest, which is determined by the coupon amount multiplied by the fraction of the coupon period that has passed.

The value of a Treasury coupon security is often expressed in terms of its yield to maturity, or yield, rather than its price. The yield on a Treasury security is the constant interest rate at which the present discounted value of future coupon and principal payments equals the current price of the security. In effect, the yield represents the rate of return an investor would earn if he or she held the security to maturity, assuming semiannual compounding of interest. By definition, the yield and the price move in opposite directions: An increase in the price implies that an investor must pay more today to receive the same, fixed payments in the future, and therefore the rate of return, or the yield, on the initial investment is lower. Although levels of yields are expressed in percentage points, researchers and market participants often express changes in yields in basis points (hundredths of a percentage point).

In contrast to coupon securities, Treasury bills are quoted in terms of a discount rate, which is the difference between the face value and the market price as a percentage of the face value, scaled to an annual rate assuming a 360-day year (that is, multiplied by 360 and divided by the number of days remaining to maturity). The yield to maturity for a Treasury bill is the difference between the face value and the market price as a percentage of the market price, scaled to an annual rate using the actual number of days in the year.

16. Michael J. Fleming, "The Round-the-Clock Market for U.S. Treasury Securities"; also Market Liquidity: Research Findings and Selected Policy Implications, Committee on the Global Financial System, Bank for International Settlements (May 1999). 


\section{Safekeeping and Transfer of Securities}

Recordkeeping for Treasury securities is done in one of two ways. In one system, ownership and legal interests are recorded electronically, in a series of book-entry records on the books of the Federal Reserve Banks and depository institutions: The Federal Reserve manages the National Book-Entry System (NBES), which maintains records for depository institutions; depository institutions, in turn, maintain records for their customers. Alternatively, an investor can maintain a book-entry securities account directly with the Treasury through the Treasury Direct system. The securities held in Treasury Direct are purchased when originally issued and are typically held to maturity.

Through the NBES, depository institutions can electronically transfer Treasury securities among themselves to settle their trades and the trades of their customers. Most of these trades are settled on a delivery-versus-payment basis whereby the securities are electronically deposited in the receiving institution's account and the corresponding payment is simultaneously electronically deposited in the sending institution's account at the Federal Reserve. The depository institutions, in turn, adjust their customers' records to reflect the transfer.

To facilitate the settlement process, the Federal Reserve grants finality when securities transfers are completed over the NBES - that is, the payments associated with these transactions are final and irrevocable. In addition, the Federal Reserve, for a fee, provides intraday credit, commonly called daylight overdrafts, to financially healthy depository institutions. To limit the credit risk arising from such credit extensions, the Federal Reserve imposes limits, based on several factors, on depository institutions' daylight overdraft capacity. The Federal Reserve requires that depository institutions cover their daylight overdrafts by the end of the day. If a depository institution ends the day with a negative account balance, the institution incurs an overnight overdraft, which carries a much higher fee than a daylight overdraft.

Because only depository institutions have access to the NBES, other buyers and sellers of government securities must use a depository institution as an intermediary ${ }^{17}$ Settlement activity is highly concentrated in a few depository institutions known as clearing banks. Clearing banks tend to be very large organizations because sizable investments in com-

17. Some government-sponsored enterprises also have access to the NBES. puter hardware and software are necessary to handle the large flow of transactions. These banks also extend intraday credit to their customers, allowing them to overdraw their money accounts to pay for securities. To finance their intraday lending to customers, clearing banks rely on daylight overdraft credit from the Federal Reserve. The charges for daylight credit are then typically passed on by the clearing banks to their customers.

\section{THE DEMAND FOR TREASURY SECURITIES}

The supply of Treasury securities, as noted earlier, is largely a function of the need to finance the cumulative budget deficits of the U.S. government. The demand for those securities is determined largely by their usefulness for investment and hedging purposes.

\section{Treasury Securities in Investors' Portfolios}

Treasury securities are held by various types of investors, including domestic financial intermediaries such as depository institutions; institutional investors; state and local governments; international investors; and the Federal Reserve System, which participates actively in the market as part of its implementation of monetary policy (chart 5).

The widespread holding of Treasury securities is an indication of several appealing characteristics. As with other fixed-income products, the payments on

5. Distribution of Treasury securities, by ownership, March 31, 1999

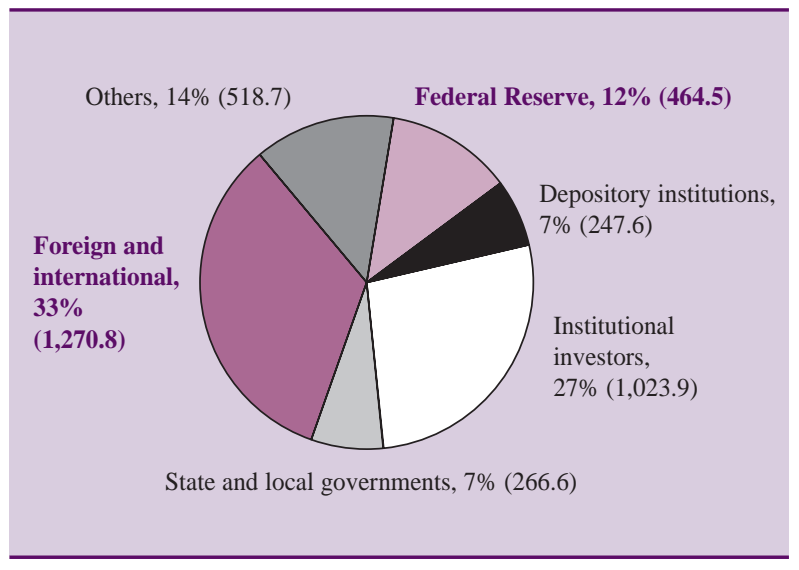

Note. Numbers in parentheses are amounts, in billions of dollars. Excludes interest-bearing public debt held in U.S. government accounts (mainly investments in the social security and federal retirement trust funds). For state and local governments, includes about $\$ 167.45$ billion of nonmarketable Treasury debt. Institutional investors include insurance companies, mutual funds, and pension funds.

Source. Treasury Bulletin, September 1999, tables OFS-1, OFS-2. 


\section{The Treasury STRIPS Market}

Although regular coupon payments may suit the needs of some investors, others may prefer securities offering a single payment when the security matures. These instruments, called zero-coupon securities, sell at a discount to their face value, allowing investors to realize a return from the increase in the price of the instrument to its maturity date.

In 1985 the Treasury initiated a program that allows investors to split a Treasury note or bond into zero-coupon securities, or STRIPS, corresponding to each coupon payment and the principal payment of the underlying security. ${ }^{1}$ For example, stripping a Treasury bond that has twenty years left to maturity generates forty coupon STRIPS, one maturing every six months for twenty years, and one principal STRIP maturing in twenty years. The final coupon STRIP and the principal STRIP are treated as distinct securities despite having identical maturity dates. Since the inception of the program, all newly issued ten-year notes and thirty-year bonds have been eligible for stripping. The program was expanded in September 1997 to include all two-, three-, and five-year notes as well.

The program also allows (as of 1987) the reconstitution of a stripped security from STRIPS matching all the security's coupon and principal payments. The principal payment needed to reconstitute a Treasury security must be generated from the principal STRIP originating from the security being reconstituted. By contrast, the coupon payment stream may be created from coupon STRIPS derived from any security; that is, coupon STRIPS with the same maturity date are fungible.

1. STRIPS is an acronym for Separate Trading of Registered Interest and Principal of Securities.
The considerable interest in zero-coupon securities was evident long before the advent of the STRIPS program. Several investment banks began holding Treasury securities with custodians in special trust accounts and selling the components of those securities to investors. The STRIPS program made this process more efficient and cost-effective, as STRIPS could be registered in the Federal Reserve's book-entry system in the same manner as other Treasury securities.

The total amount of STRIPS outstanding increased rapidly following the introduction of the program, reaching $\$ 200$ billion by 1993 before leveling out. Stripping activity has been concentrated in longer-term securities, possibly because stripping makes it possible to create Treasury securities having longer duration than available from couponbearing Treasury securities, which may be of interest to investors having very long investment horizons. At the end of September 1999, about 32 percent of all outstanding Treasury bonds were held in stripped form. Stripping activity has been more limited for securities having shorter maturities, in part because stripping simply replicates many of the zero-coupon securities that are created by stripping longer-term securities.

The STRIPS market is characterized by heavy flows of gross stripping and reconstitution activity, with an average of about $\$ 11$ billion of securities stripped and reconstituted each month over the first three quarters of 1999. Stripping and reconstitution transactions can be implemented relatively quickly and at very little cost, facilitating arbitrage between the markets. As a result, there is a relatively tight pricing relationship between a strippable Treasury security and its stripped components. nominal Treasury securities are specified in advance, providing the investor with a known stream of income. (Investors who prefer a single future payment rather than a stream of coupon payments may instead hold STRIPS, described in the box "The Treasury STRIPS Market.") Fixed-income securities are often an important component of well-balanced portfolios that seek to minimize the variance of returns for a given expected return.

Treasury securities are particularly appealing to investors because they offer greater safety and liquidity than other fixed-income securities. The payments of principal and interest on the securities are backed by the full faith and credit of the U.S. government. In light of the sound financial history of the federal government and its ability to raise substantial tax revenues, Treasury securities are considered to have the lowest risk of default of any major financial investment in the world. Moreover, the interest income derived from Treasury securities is exempt from state and local taxes. In addition, some Treasury securities are extremely liquid, which may be particularly important to investors engaging in hedging and other trading-intensive investment activities. Demand arising from such activities is not spread evenly across all Treasury securities but is concentrated in a limited number of issues with superior liquidity (as discussed in the section "Factors Affecting Individual Treasury Securities").

Liquidity is an important factor influencing the Federal Reserve's holdings of Treasury securities as well. The Federal Reserve tends to hold Treasury securities having maturities shorter than the average maturity of marketable securities held by other investors, partly because securities having shorter maturities tend to be more liquid and because it can fairly 
rapidly reduce the size of its holdings of such securities, should it need to, by merely not replacing maturing holdings. The advantages of holding a liquid portfolio became evident in 1984 when the Federal Reserve had to sell a significant amount of Treasury securities to offset the massive influx of reserves into the banking system provided through a large volume of discount-window loans at the time. ${ }^{18}$ The Federal Reserve reduced the maturity of its portfolio from about four years in 1985 to about three years in 1991. In 1992, the Federal Reserve's policymaking committee decided that the portfolio had reached a sufficient level of liquidity and instructed the trading desk at the Federal Reserve Bank of New York to keep the average maturity from falling further. In the following years, because of the paydown of Treasury bills outstanding, the average maturity crept back up to about four years.

Overall, Treasury securities may appeal to investors seeking the safety and liquidity offered by those securities, and the securities' prices are determined by the value investors ascribe to those characteristics in the context of their investment strategies.

\section{Determinants of the Yield Curve}

The values of Treasury securities are often summarized by the yield curve, which plots the yields of all noncallable securities against their maturities. An example is the yield curve on September 23, 1999 (chart 6). This curve has an upward-sloping, concave shape. Securities having maturities of less than five years are highly concentrated because shorter-term

18. Cheryl L. Edwards, "Open Market Operations in the 1990s," Federal Reserve Bulletin, vol. 83 (November 1997), pp. 859-74.

\section{Yield curve for Treasury securities, September 23, 1999}

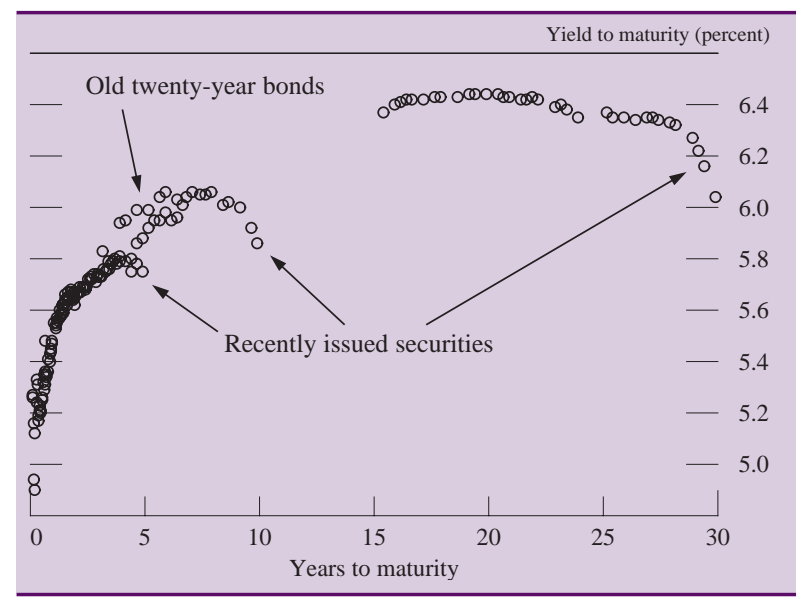

Source. Federal Reserve Bank of New York. securities are auctioned more frequently and because many previously issued longer-term securities fall in that maturity range. The gap between noncallable securities having maturities of ten years and fifteen years arises because the Treasury switched from issuing twenty-year bonds to issuing thirty-year bonds in the mid-1980s.

Securities having similar maturities tend to have similar yields because they offer fixed payments over similar periods. Securities having very different maturities are also linked. In particular, longer-term interest rates generally reflect expectations about the future path of short-term interest rates. This relationship, which is often referred to as the expectations hypothesis, arises because an investor can choose among several strategies, including purchasing a Treasury security whose maturity extends over his or her investment horizon or purchasing a short-term security and continuing to reinvest in that security (that is, roll it over) through the investment period. ${ }^{19}$ The former strategy offers a return equal to the yield on the longer-term security, whereas the latter offers a return determined, approximately, by the average of the yields on the short-term security over the investment horizon. ${ }^{20}$ Substitution between the two strategies tends to keep the expected returns from the two strategies close to one another, although not exactly equal because of differences in risk (discussed below).

Yields on short-term Treasury securities are importantly influenced by monetary policy decisions by the Federal Reserve. Under current operating procedures, the Federal Reserve sets a target level for the federal funds rate - the rate at which depository institutions make uncollateralized overnight loans to one another. Yields on short-term securities do not deviate substantially from that rate because the institutions are able to substitute between making short-term loans in the federal funds market and purchasing Treasury securities having very short maturities. ${ }^{21}$

Longer-term yields, because they reflect expectations of future short-term yields, can be significantly influenced by the outlook for monetary policy. For

19. The vast literature on the yield curve includes alternative versions of the expectations hypothesis as well as many criticisms. This article merely notes a general relationship between longer-term yields and expectations about future short-term interest rates without taking a stand on any particular variant of the expectations hypothesis.

20. Rates on longer-term Treasury securities are actually related to a weighted average of future short-term rates, where the pattern of the weights is determined by the size of the coupon payment on the longer-term instrument.

21. The relationship between yields on short-term Treasury securities and the federal funds rate is not exact, in part because of differences in tax treatment and credit risk. 


\section{Yield curve for Treasury securities}

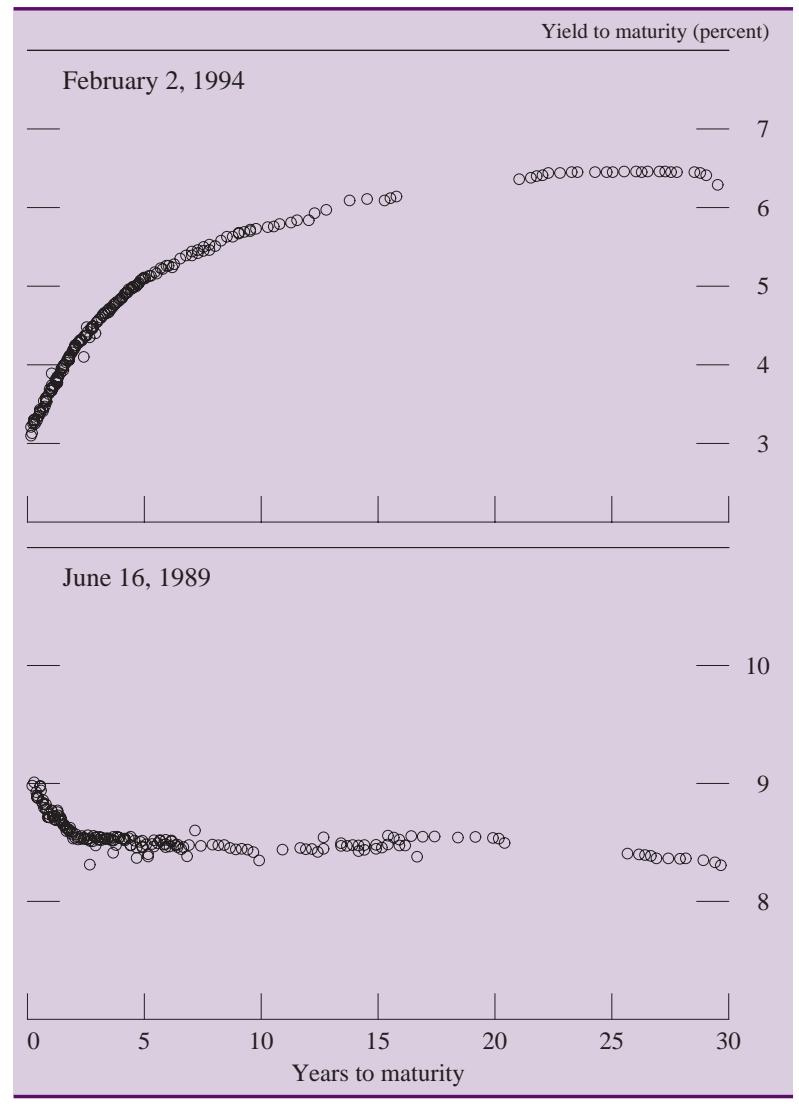

Source. Federal Reserve Bank of New York.

example, the yield curve was very steep on February 2,1994, prior to a sequence of monetary policy tightenings that hiked the federal funds rate target 3 percentage points over the next twelve months (chart 7). In contrast, on June 16, 1989, yields on long-term bonds were below those on short-term securities before a sequence of policy easings that cut the target federal funds rate about $3 \frac{1 / 2}{2}$ percentage points over the subsequent twenty-four months.

Some differences in yields on Treasury securities are not related to expected future movements in interest rates. These differences for the most part reflect compensation for risk and are often referred to as term premia. Although they are viewed as free of default risk, Treasury securities involve interest rate risk, as movements in their yields generate capital gains or losses for investors. ${ }^{22}$ The uncertainty surrounding the return from holding a Treasury security

22. Some of the movements in yields may occur in response to expected changes in inflation. Unexpected movements in inflation that are not reflected in Treasury yields also present a risk to investors by eroding the purchasing power of the returns on the security. The risks presented by inflation are discussed in more detail in the section on inflation-indexed securities.
3. Characteristics of selected Treasury securities, December 1987-September 1999

\begin{tabular}{c|c|c|c|c}
\hline \multirow{2}{*}{ Security } & \multicolumn{2}{|c|}{ Average } & \multicolumn{2}{c}{ Standard deviation } \\
\cline { 2 - 5 } & $\begin{array}{c}\text { Duration } \\
\text { (years) }\end{array}$ & $\begin{array}{c}\text { Yield } \\
\text { (percent) }\end{array}$ & $\begin{array}{c}\text { One-month } \\
\text { change in } \\
\text { yield } \\
\text { (basis points) }\end{array}$ & $\begin{array}{c}\text { One-month } \\
\text { holding } \\
\text { return } 1 \\
\text { (percentage } \\
\text { points) }\end{array}$ \\
\hline Two-year note ..... & 1.81 & 6.24 & 30.2 & 1.93 \\
Five-year note ..... & 4.29 & 6.72 & 29.9 & 4.27 \\
Ten-year note ..... & 6.91 & 7.03 & 26.9 & 6.43 \\
Thirty-year bond .. & 11.95 & 7.34 & 23.1 & 9.39 \\
\hline
\end{tabular}

Note. Data are for the most recently issued security in each maturity class.

1. Standard deviation of monthly holding returns expressed at an annual rate, assuming that monthly returns are independent across time.

Source. Federal Reserve Bank of New York; authors' calculations.

depends on the amount of variation in the yield on that security and on the sensitivity of the price of the security to changes in yields. The latter is determined by the duration of the security, which is given by a mathematical formula that summarizes how far into the future, on average, the payments of a security are to be made. The duration of a zero-coupon bond, because it makes only a single payment, equals its maturity. The duration of a coupon-bearing security, because it makes coupon payments before it matures, is less than its maturity.

Longer-term bonds tend to have more interest rate risk because they have longer duration. Intuitively, the price of these securities must change more for a given change in yield because the change in yield must be realized over a longer period. The effects of longer duration are evident in table 3 , which presents some summary statistics on yields and one-month holding returns (including coupon payments and capital gains or losses) for securities with different maturities. Yields tend to vary less as the security's maturity increases, indicating (according to the expectations hypothesis) that many of the movements in shorter-term yields are expected to be transitory. However, this pattern is more than offset by differences in the duration of the securities, so that over the period considered, the standard deviation of the holding return for the thirty-year bond was nearly five times greater than that for the two-year note. Because investors typically demand a premium for bearing additional risk, longer-term Treasury securities, on average, offer higher yields than shorter-term instruments. ${ }^{23}$ Indeed, for this sample the average

23. The amount of variation in holding returns is not necessarily the measure of risk considered by investors. Most finance models indicate that the covariance of holding returns with the returns on other assets or with changes in consumption determines the risk premium on an asset. 
yield on the thirty-year bond was more than a full percentage point higher than that on the two-year note. In general, the greater risk of holding longerterm securities imparts an upward-sloping shape to the yield curve.

The expected return from holding a Treasury security depends not only on the level of its yield but also on the volatility of its yield. The reason is that the increase in the price of the security resulting from a decline in its yield is greater in magnitude than the decrease in the price resulting from a equal-size rise in its yield. If the uncertainty surrounding future yield changes is symmetric, potential capital gains will exceed potential capital losses, increasing the expected return. As a result, the yield on a Treasury security can fall below its expected return by the amount that is gained from the imbalance in potential returns. The magnitude of this effect-often referred to as the convexity premium-increases with the security's maturity. The convexity premium is often thought to add curvature to the shape of the yield curve by pushing down longer-term yields more than shorter-term yields.

\section{Factors Affecting Individual Treasury Securities}

Although the factors described in the preceding section largely determine the overall shape of the yield curve, there is also considerable variation among the yields on individual Treasury securities having similar maturities. Some of this variation reflects additional characteristics of the Treasury market that affect the yields of particular securities.

\section{Liquidity}

Overall, the Treasury market is extraordinarily liquid. Enormous amounts of securities are traded every day. Even counting only the transactions of the primary dealers, the value of the entire stock of marketable Treasury debt would turn over completely in about three weeks. The considerable trading volume allows market participants to move in and out of large Treasury positions rapidly with little effect on the prices of those securities. Because of the extensive trading and the high degree of competition and transparency among dealers, dealers typically make markets in Treasury securities at narrow bid-offer spreads. Bid-offer spreads for Treasury securities are reported to be $1.6 \varnothing$ or less per $\$ 100$ face value. By comparison, bid-offer spreads for investment-grade corporate bonds average about $13.3 \phi$ and for highyield corporate bonds, $19.1 \not .^{24}$

The liquidity of the Treasury market is not evenly distributed across securities, however. Most of the trading activity takes place in on-the-run issues-the most recently issued securities in a particular maturity class. The difference in trading volume between on-the-run securities and previously issued (off-therun) securities is striking. In recent years, more than half of reported interdealer broker trading in nominal Treasury debt, on average, took place in on-the-run securities, even though off-the-run issues outnumbered on-the-run issues more than twenty to one. ${ }^{25}$

Because of the remarkable liquidity of on-the-run Treasury securities, some investors are willing to pay a premium for (that is, accept a lower yield for) those securities compared with similar, off-the-run securities. The preference for liquidity was evident in the number of securities trading at yields that deviated from the rest of the yield curve on September 23, 1999 (chart 6). Yields on recently issued five-, ten-, and thirty-year securities were well below those on off-the-run securities with similar maturities. In contrast, some securities traded at yields notably above the curve, including long-ago-issued twenty-year bonds that are much less liquid. ${ }^{26}$ At times, the market's preference for liquidity becomes acute, and spreads between on-the-run and off-the-run issues widen appreciably, as observed during the market turmoil in fall 1998 (see box "The Flight to Quality and Treasury Yields").

\section{Hedging Demand}

Treasury securities are also commonly used as hedging instruments, primarily to offset the interest rate risk inherent in positions in other fixed-income securities. Dealers often have positions in other fixedincome products, including corporate debt securities and mortgage-backed securities, arising in part from their role in issuing and making markets in such securities. Dealers may also choose to establish large

24. Figures for corporate debt securities are from G. Hong and A. Warga, "An Empirical Study of Bond Market Transactions," Financial Analysts Journal (forthcoming).

25. Volume data are collected by GovPX, a joint venture of primary dealers and some interdealer brokers that reports data on transactions taking place through five of the six interdealer brokers. Reported trading volume primarily captures dealer-to-dealer trades. Retail and institutional investors may trade off-the-run issues in greater proportion than dealers.

26. Market participants may also be reluctant to hold the twentyyear bonds because institutional considerations may make it less appealing to purchase securities that have coupon rates well above current yields. 


\section{The Flight to Quality and Treasury Yields}

Treasury securities generally have lower yields than other fixed-income products because of their safety and liquidity. At times, the market's concern about risk and liquidity has become pronounced, resulting in a "flight to quality" into Treasury securities despite their lower yields.

Such a flight occurred in the fall of 1998. After the devaluation of the Russian ruble in August of that year and subsequent difficulties in other emerging-market economies, investors' aversion toward risk appeared to intensify. That sentiment was reinforced by the prospect of a default by Long-Term Capital Management, a prominent hedge fund that in August and September had sustained sharp losses from its investment positions. By generating sizable losses for the firm's counterparties and forcing the abrupt unwinding of the firm's extensive positions in the Treasury and other markets, a default could have significantly disrupted markets. ${ }^{1}$

Liquidity in many markets declined sharply over this period, with bid-offer spreads widening and large transactions becoming more difficult to complete. Anecdotal reports suggest that bid-offer spreads on Treasury securities widened from their normal levels of $1.6 \phi$ or less per $\$ 100$ to as high as $16 \phi$ for on-the-run issues and $25 \phi$ for off-the-run issues. Moreover, investors showed a dramatic preference for the greater liquidity offered by on-the-run issues. Yield spreads between the most recently issued and second most recently issued securities (the liquidity premium on on-therun securities) widened sharply, as investors were willing to hold the more liquid securities at lower yields (chart).

The increased concern about liquidity and the reduced willingness of investors to bear risk also caused a widening of spreads between other fixed-income securities and Treasury securities. The widening affected even highly rated

1. Hedge Funds, Leverage, and the Lessons of Long-Term Capital Management, Report of the President's Working Group on Financial Markets (April 1999).
Indicators of increased concern about liquidity and risk

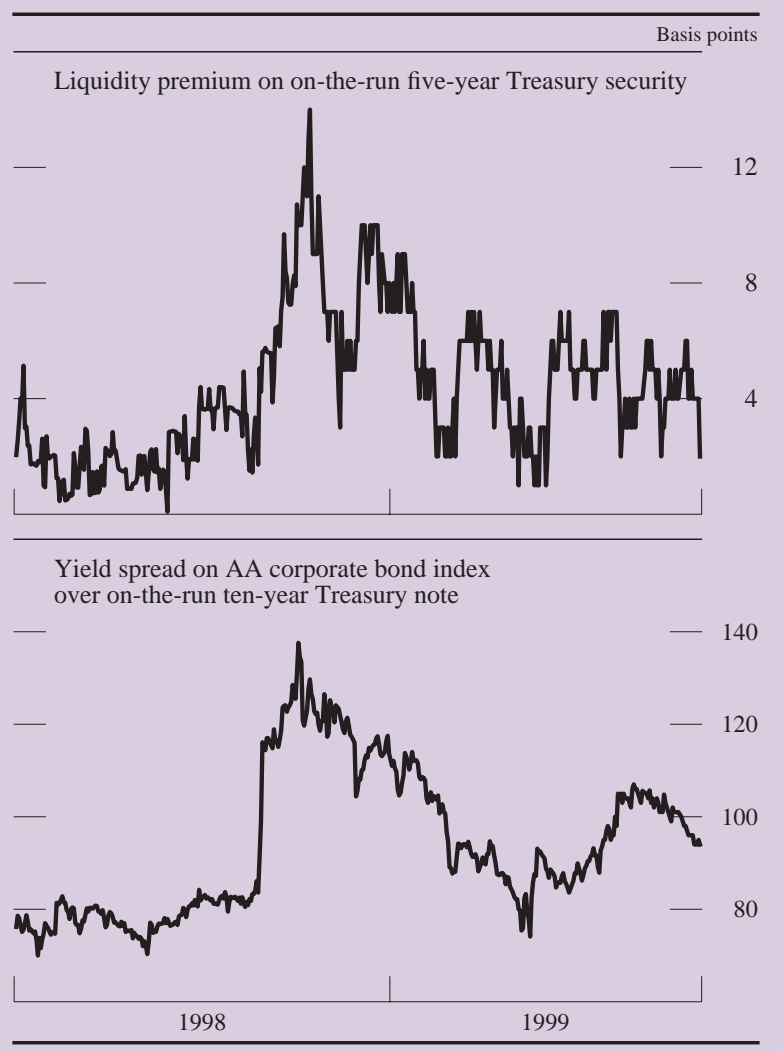

Note. Data are daily and extend through October 1999. SOURCE. Bloomberg.

debt. Market strains began to subside following the Federal Reserve intermeeting policy easing on October 15, 1998. Soon thereafter, bid-offer spreads on Treasury securities, premiums for on-the-run issues, and yield spreads between government-sponsored enterprise and Treasury securities began to decline. positions in non-Treasury fixed-income products as part of their portfolio strategies.

To hedge the interest rate risk associated with those positions, dealers frequently take short positions in Treasury securities. As described in more detail below, the short position is established by selling securities that the dealer does not own but instead borrows, with the intention of purchasing those securities at a later time. By doing so, the dealer profits if yields rise, which could offset some of the losses incurred in long positions in other fixedincome securities.

Several characteristics of Treasury securities make them well suited for hedging positions in other fixed- income products. Probably most important is their remarkable liquidity. Because their balance sheet positions can change rapidly, dealers want to be able to quickly alter their holdings of the hedging instrument in order to maintain the proper hedges. Therefore, a preferred hedging instrument is one that can be traded quickly and at little cost. A second characteristic is that dealers can readily establish short positions in these instruments at reasonable costs because the repo market in Treasury securities is active (discussed in the next section).

Of course, Treasury securities and their derivatives do not offer a perfect hedge against movements in the value of other types of debt instruments. This became 
apparent in the fall of 1998, when investors became increasingly concerned about the safety and liquidity of their investments. ${ }^{27}$ The ensuing "flight to quality" (see box) pushed down yields on Treasury securities sharply relative to yields on corporate and mortgage-backed debt securities (some of which actually rose), generating large losses in short positions in Treasury securities that were not offset by gains in other fixed-income securities. Since that time, market participants have evinced an increasing reliance on non-Treasury securities for their hedging needs, including debt issued by governmentsponsored enterprises.

\section{Related Markets}

The demand for Treasury securities is also importantly affected by the markets for repurchase agreements and derivatives.

\section{Repurchase Agreements}

Dealers and other investors often establish short positions in Treasury securities as part of their hedging activity or, more generally, as part of their portfolio strategies. To establish short positions, they sell securities they do not own and deliver those securities to the purchaser by obtaining them in the market for repurchase agreements, the repo market.

The repo market allows participants to exchange funds and securities on a temporary basis-in effect, borrowing and lending using Treasury and other debt securities as collateral. More specifically, a firm engaging in a repo transaction simultaneously sells a particular security to a counterparty and agrees to repurchase that same security at a specified price at a later date, often the next day. This firm is said to "repo out" the security, by which it borrows money at what is called the repo rate, which is based on the difference between the current price and the agreed-to future price. A reverse repo is simply the other side of the transaction-agreeing to purchase particular securities temporarily and to resell them to the same counterparty at a specified price at a later date. In this case, the firm "reverses in" the security.

Investors can therefore deliver securities that they sold short by reversing in the securities repeatedly until they decide to cover the position by purchasing

27. A Review of Financial Market Events in Autumn 1998, Committee on the Global Financial System, Bank for International Settlements (October 1999). the securities outright. On the other side, investors frequently rely on the repo market to finance their long positions in Treasury securities by repoing out those securities. Partly as a result of these activities, trading volume in the repo market is heavy: Primary dealers reported about $\$ 1.2$ trillion of lending and borrowing in the repo market on their balance sheets as of October 20, 1999.

Most repo transactions involving Treasury securities take place at what is called the general-collateral repo rate. This interest rate typically follows the federal funds rate closely, as depository institutions can use either market as a source of overnight financing. ${ }^{28}$ However, if the demand for a particular Treasury security in the repo market is sufficiently high, or if the supply of that security is limited, the repo rate for that security can fall below the generalcollateral repo rate. In such a case, the security is said to go "on special" in the repo market. The firm reversing in the desired security is willing to pay a cost to obtain that security by letting the holder of the security borrow at an interest rate below the general market rate.

This situation frequently arises in on-the-run Treasury securities, as these issues are heavily used in establishing short positions for hedging and other purposes, resulting in considerable demand for them in the repo market. The repo rate for the on-the-run ten-year note has often fallen several percentage points below the general-collateral repo rate (chart 8). Researchers have found that the "specialness" of an on-the-run issue - the difference between its repo rate and the general-collateral rate-tends to build following an auction as a larger proportion of the issue comes to be held by investors who do not make the security available to the repo market. The specialness typically peaks around the announcement of the next auction, after which it declines as short positions begin to shift to the next on-the-run issue. ${ }^{29}$ In addition to this regular pattern, other factors influence the specialness of these securities. For example, increased hedging activity around periods of heavy issuance of corporate debt or mortgage-backed securities can lead to sizable short positions that cause particular securities to go on special in the repo market.

Securities that are on special in the repo market frequently trade at lower yields (higher prices) than

28. The main difference between the transactions is that a repo transaction is akin to a collateralized loan, whereas a federal funds transaction is an uncollateralized loan.

29. Frank Keane, "Repo Rate Patterns for New Treasury Notes," Federal Reserve Bank of New York, Current Issues in Economics and Finance, vol. 2 (September 1996). 
8. Overnight repo rates for Treasury securities, 1995-99

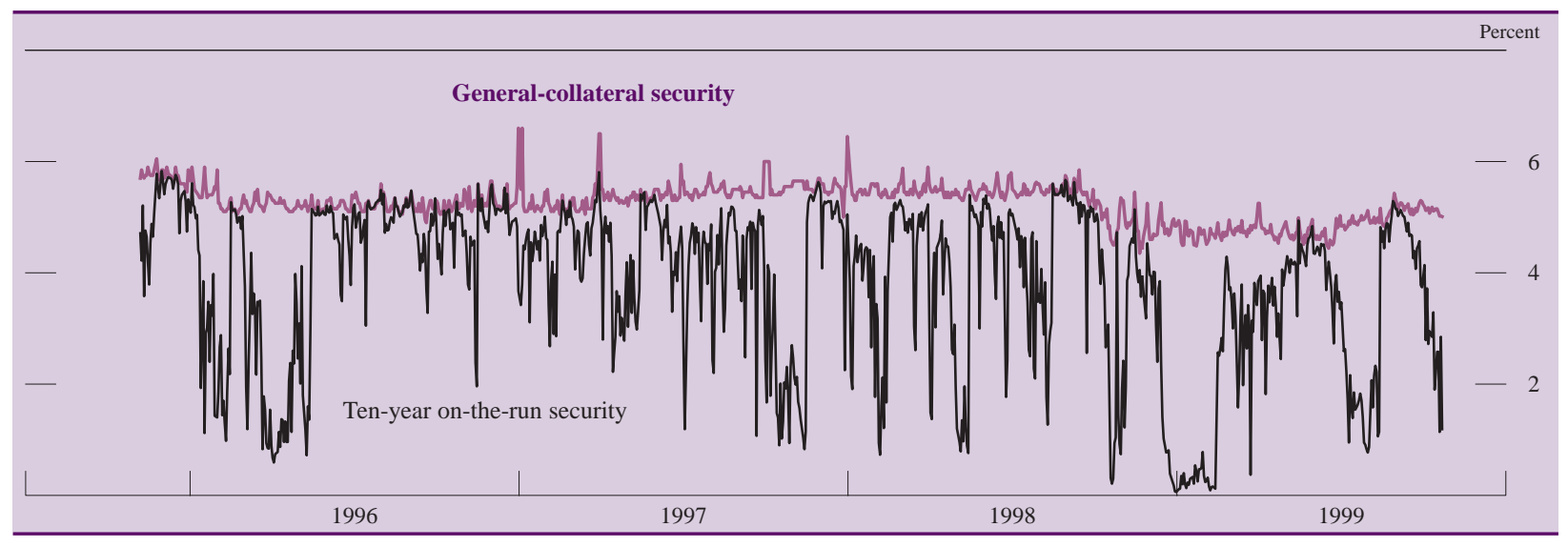

Note. Data are daily and extend from November 7, 1995, to October 22, 1999.

other securities with comparable maturities, as is often the case for on-the-run Treasury securities. ${ }^{30}$ If a security is on special in the repo market, holders can realize a profit by borrowing against the security at below-market rates; because this profit increases the return on the security for a given yield, investors may be willing to hold the security at a lower yield. However, investors that value the greater liquidity of on-the-run securities may be willing to hold them without repoing them out despite their lower yields.

The patterns observed around Treasury auctions, which reflect the activity associated with bringing new issues to market, account for a significant portion of the movements in yields and repo rates for the most recently issued securities. However, extensive specialness in the repo market has at times also signaled severe shortages of particular Treasury securities that have disrupted the effective functioning of the market for those securities. Several such shortages took place around the time that Salomon Brothers admitted in 1991 to repeated violations of Treasury auction rules. In response, several regulatory and policy changes were implemented to prevent violations of auction rules and to alleviate such shortages if they develop (see box "Regulatory Reforms").

To facilitate transactions in the repo market, the Federal Reserve Bank of New York operates a securities lending program that allows primary dealers to borrow individual Treasury securities from the Federal Reserve's portfolio overnight by posting a different Treasury security as collateral. The program uses

30. For a discussion of the repo market and its effects on Treasury yields, see Darrell Duffie, "Special Repo Rates," Journal of Finance, vol. 51 (June 1996), pp. 493-526. a competitive auction format. Under the current structure, initiated on April 26, 1999, the Bank conducts a daily auction at which it accepts bids in terms of a "lending fee" for borrowing particular securities. When a bid is accepted, the particular security is delivered to the dealer's account. The dealer, in turn, delivers a different Treasury security to the Federal Reserve as collateral and pays the lending fee. The lending fee is closely related to the spread between the general-collateral repo rate and the repo rate for the borrowed security, because from the dealer's perspective the transaction is similar to repoing out a (general-collateral) security and reversing in the desired security. The minimum bid is 150 basis points, high enough that borrowing activity is limited to those securities that are scarce, and hence deeply on special, in the repo market.

The Federal Reserve's portfolio of Treasury securities as of October 31 of this year totaled $\$ 492$ billion. By making a portion of these holdings available for borrowing, the securities lending program increases the potential supply of Treasury securities available to the repo market, which should help reduce the scarcity of particular issues. The Federal Reserve originally stood ready to lend up to 25 percent of its holdings of any security but on September 7, 1999, increased the limit to 45 percent. Over the two months following the increase, dealers borrowed an average of about $\$ 1.4$ billion of Treasury securities, typically distributed across several different securities, every business day.

\section{Derivatives}

A large and active market exists for derivative securities whose values are based on the prices of Treasury 


\section{Regulatory Reforms Following Violations of Auction Rules by Salomon Brothers}

Following the April and May 1991 Treasury auctions, several widely publicized "short squeezes" occurred in the two-year note during which an apparent scarcity of the securities caused their yields and repo rates to fall substantially below those for other Treasury securities. The information available to the Treasury suggested that the May squeeze had resulted from a concentration of auction awards to Salomon Brothers and some of its customers. In addition, there had earlier been inquiries into several Salomon Brothers bids at the February 1991 auction of the five-year note that appeared to violate the rule limiting the amount bid by a single bidder to 35 percent of the publicly offered amount.

These events prompted investigations by the Securities and Exchange Commission (SEC) and the Antitrust Division of the Department of Justice, leading Salomon Brothers to conduct its own investigation. In August 1991, the firm admitted to submitting unauthorized customer bids at several auctions in 1990 and 1991 and to failing to report large net long positions on auction tender forms as required. Subsequently, the Treasury, the SEC, and the Federal Reserve jointly reviewed the government securities market and issued a report describing a number of policy and regulatory changes aimed at improving the functioning of the market and avoiding such violations in the future. ${ }^{1}$ Some of the reforms were implemented immediately, and others were recommended for legislative approval.

Many of the reforms were intended to make Treasury auctions accessible to more participants. The set of firms allowed to submit bids for customers was broadened to include all government securities brokers and dealers, not just primary dealers and depository institutions. The requirements for becoming a primary dealer were loosened by eliminating the rule that to qualify the dealer must account for at least 1 percent of the dollar volume of all customer trades in the secondary market. In addition, the maximum for noncompetitive tender awards for notes and bonds was raised from $\$ 1$ million to $\$ 5$ million; however, to ensure that noncompetitive awards were reserved for the smaller bidders for whom they were intended, noncompetitive bids were restricted to bidders having no positions in the when-issued, futures, or forward markets at the time of the auction and not submitting competitive bids.

1. Joint Report on the Government Securities Market (Washington, DC: Government Printing Office, January 1992).
Other changes were aimed more directly at the enforcement of auction rules. Customer bids are now spot-checked by the Federal Reserve Bank of New York to ensure their authenticity, and all large auction awards are now confirmed directly with the customer. The report also emphasized the need to automate the auction procedure, which has since taken place.

The report also considered the benefits of replacing the then-current multiple-price auction system for notes and bonds with a uniform-price system, under which all successful bidders would be awarded securities at the lowest price. The report suggested that such a change might alleviate some concern among auction participants about bidding above the market consensus. Consequently, more investors might bid on their own rather than through primary dealers, reducing the primary dealers' advantage at the auctions that arises from knowing the bidding intentions of their customers. The Treasury subsequently began an experiment with this auction method for two- and five-year notes. By November 1998, all Treasury securities were being auctioned on a uniform-price basis.

In addition, some changes were implemented to detect and respond to short squeezes in the secondary market. A group made up of representatives of the SEC, the Treasury, the Federal Reserve Bank of New York, and the Board of Governors of the Federal Reserve System was established to improve surveillance efforts. The Treasury stated its intention to reopen any security that was experiencing an "acute, protracted" shortage in order to increase the supply of the security. The reopening could be implemented in several different ways, one of which is to immediately auction an amount sufficiently large to eliminate the possibility that the squeeze would persist.

Finally, the Congress enacted the Government Securities Act Amendments of 1993. Among other provisions, the amendments give the Treasury the authority to require holders of large positions in a particular security to report on their positions if a shortage emerges. The Treasury has conducted two tests of the reporting system, one in June 1998 and the other in July 1999. In both cases, the Treasury required investors with reportable positions in excess of $\$ 2 \frac{1}{2}$ billion in the specified security to file large-position reports. securities. Futures and options contracts for two-, five-, and ten-year notes and for bonds are listed by the Chicago Board of Trade (CBOT), and similar futures contracts are offered on the Cantor Financial Futures Exchange. In addition, the Chicago Mercantile Exchange offers options and futures on various Treasury bills and other short-term interest rate products.
As of the end of October 1999, open interest for CBOT long-bond futures (that is, the total number of contracts held by market participants) was about 635,000 , with each contract based on $\$ 100,000$ face value of the Treasury bond. Daily trading volume in these contracts over the month averaged about 300,000 contracts. The CBOT also offers trading in options on Treasury futures (contracts that allow the 
holder to buy or sell a futures contract at a specified price). For options on long-bond futures, open interest totaled about 950,000 contracts and daily trading volume averaged about 130,000 contracts. Because of the liquidity of this market, combined with the ease with which investors can establish "short" positions by selling futures contracts, these instruments are also commonly used for hedging purposes.

The seller of a CBOT Treasury futures contract agrees to deliver a Treasury security to the purchaser of the contract at a specified price at a future date. Most positions in these futures contracts are closed out prior to delivery by entering into offsetting trades, and delivery does not take place. However, the possibility of delivery links the price of the contract to the deliverable Treasury securities. Typically, several securities are eligible for delivery into the contract. ${ }^{31}$ The long-bond futures contract, for example, allows any Treasury bond with more than fifteen years remaining to maturity at the expiration of the contract to be delivered (for the March 2000 contract, thirtyfive such securities are eligible).

One of the securities eligible for delivery is the "cheapest to deliver." That is, the cost to the seller of the futures contract of purchasing the security to make delivery will be lower than the cost of delivering any other eligible security. The price of the contract is influenced primarily by the value of the cheapest-to-deliver security. Moreover, the cheapestto-deliver status has at times significantly affected the yield of that Treasury security. In particular, the cheapest-to-deliver security is often traded more actively as market participants hedge their futures position, which enhances the security's liquidity. Because of this enhanced liquidity and because some investors may need to purchase the security to make delivery into the futures contract, the cheapest-todeliver security may trade at a premium to Treasury securities having similar maturities.

\section{RECENT DEVELOPMENTS AFFECTING THE MARKET}

The structure and behavior of the Treasury market is continually changing. Some of the developments and emergent trends that have recently influenced the market are discussed in this section.

31. Eligible securities trade at a premium or a discount to face value simply because of differences in their coupon rates. To adjust for this effect, the CBOT contract scales the invoice amount-the amount that the investor who is long the futures contract must pay upon receiving an eligible security-by a "conversion factor" for that security.
Availability of a New Instrument: Inflation-Indexed Securities

A significant innovation in the Treasury market in the past several years has been the introduction of a new type of debt instrument: Treasury inflationindexed securities, or TIIS. ${ }^{32}$ Since the program's inception in January 1997, about $\$ 92$ billion of TIIS have been issued. ${ }^{33}$ Unlike previously issued Treasury securities, the coupon and principal payments on TIIS increase with a measure of the general price level-the consumer price index (CPI). Indexation provides protection against the possibility that inflation will erode the amount of goods and services that could be purchased with the interest or principal payments.

\section{The Mechanics of TIIS}

Whereas the principal amount of a nominal Treasury security remains fixed in nominal terms, the principal amount on a TIIS adjusts over time by the rate of inflation. The value of the principal on a given day is calculated by multiplying the principal amount at issuance by a daily index ratio determined by a reference CPI for that day divided by the reference CPI on the day of issue. The reference CPI is based on the non-seasonally adjusted CPI lagged about two and one-half months, as published by the Bureau of Labor Statistics (BLS). ${ }^{34}$

If the average rate of inflation is positive, the principal amount of the TIIS generally rises over the life of the security. ${ }^{35}$ Coupon payments will also increase in line with the rate of inflation, as coupon

32. Several government-sponsored enterprises, corporations, and local governments followed the Treasury's lead by issuing indexed debt in early 1997. In addition, the Treasury began selling inflationindexed savings bonds, called I-bonds, in September 1998.

33. When adjusted for the accrual of inflation compensation, the total amount of TIIS outstanding is higher than this amount.

34. Specifically, the CPI refers to the non-seasonally adjusted U.S. City Average All Items Consumer Price Index for All Urban Consumers. The reference CPI for the first day of a given month is the CPI reported for the third preceding calendar month, and the reference CPI for days over the rest of the month is a weighted average of the reference CPI figures on the first days of the current month and the following month. The lag involved in calculating the index ratio is unavoidable because the monthly CPI is released with a lag and the reference CPI for the beginning of the following month must be known.

35. A period of deflation could decrease the principal amount of the TIIS. However, the TIIS program provides that the cumulative adjustment to the principal amount at the maturity of the security may not be negative. 
payments on TIIS are determined by the specified coupon rate multiplied by the principal amount. The quoted prices of TIIS do not reflect the accumulated amount of inflation compensation; the value of the security exchanged when a TIIS is traded is the quoted price multiplied by the current index ratio plus the amount of accrued interest.

TIIS do not offer perfect protection against inflation risk, for several reasons. First, TIIS holders face some inflation risk because of the lag involved in calculating the reference index. Second, holders pay taxes on inflation compensation, so the degree of inflation protection is reduced by an investor's tax rate. ${ }^{36}$ In addition, TIIS holders face some risk that the method used to calculate the CPI will change. ${ }^{37}$ The BLS has implemented several methodological changes in recent years, partly in response to recommendations by the Boskin Commission, an advisory group appointed to study the CPI. Some market participants estimate that these changes have shaved about 0.7 percentage point from the index's annual rate of growth. Such a reduction directly affects the rate at which payments on TIIS increase, and hence the value of TIIS. The risk of additional changes in the method of calculating the CPI may result in a risk premium in TIIS yields; however, many market participants believe that most of the likely changes have already been implemented.

\section{The Potential Appeal of TIIS}

The protection against inflation provided by TIIS, previously unavailable in the Treasury market, may be valued by investors, who tend to be concerned about real rates of return (that is, about the amount of goods and services they will be able to purchase with the payments from a security). Because the payments automatically adjust to compensate for inflation, the yield on an inflation-indexed security reflects the real rate of return that would be realized over the maturity of the security. The yield on a nominal security, in contrast, includes not only the anticipated real return on the security, but also compensation for inflation. This inflation compensation includes the expected

36. This effect is inconsequential if TIIS are held in nontaxable accounts. The taxation of the inflation compensation on TIIS is comparable to that for nominal Treasury securities, on which the inflation compensation (embedded in the coupon rate) is also taxed.

37. If the CPI is discontinued or substantially altered in a manner that is deemed "materially adverse to the interests of an investor," the Treasury, in consultation with the BLS, will substitute an appropriate alternative index. However, incremental improvements in the CPI do not receive special treatment. level of inflation as well as an inflation risk premium, as described below.

By holding an inflation-indexed security to maturity, an investor can lock in a long-term real rate of return, a strategy that may be appealing to investors with long investment horizons. Investors with shorter horizons also can protect themselves against inflation by holding TIIS, although they are subject to real interest rate risk; that is, changes in TIIS yields will generate capital gains or losses that depend on the duration of the security.

However, the risks from holding TIIS are likely to be smaller than those from holding nominal Treasury securities. In addition to real interest rate risk, returns on nominal securities are subject to the risks presented by unpredictable changes in inflation. An increase in expected inflation, for example, typically causes yields on nominal Treasury securities to rise (assuming that investors demand the same real return going forward), generating capital losses for current investors. In contrast, TIIS would maintain the same real return without a change in yields, and thus holders of TIIS would not suffer any capital losses. ${ }^{38}$ By eliminating this "inflation risk," TIIS may offer more stable real returns than nominal Treasury securities.

Thus, investors may demand a higher expected real return on nominal Treasury securities than on TIIS to compensate them for the additional risks of holding those securities. ${ }^{39}$ By issuing indexed debt, the government, rather than the investor, assumes the risks associated with unpredicted changes in inflation and therefore does not have to pay this "inflation risk premium" to the investor, which may lower the government's cost of borrowing.

An additional benefit of issuing TIIS, it has been argued, is that yields on indexed debt might provide policymakers with a timely and informative measure of market expectations about real interest rates. In that case, the difference between yields on TIIS and yields on nominal Treasury securities - the measure of inflation compensation on nominal securitiesmay contain valuable information about investors' outlook for inflation. This measure of inflation compensation reflects primarily the expected level of inflation over the maturity of the instruments plus the

38. In addition, TIIS protect investors from unexpected changes in inflation that are not reflected in nominal yields. Such changes would not generate capital losses on nominal Treasury securities but would still erode the real returns on those securities.

39. The measure of risk considered here is the variation in real returns. Investors may instead be concerned about the covariance of returns with the returns on other assets or with changes in consumption. 
inflation risk premium, but it may also be influenced by differences in the liquidity of the securities. ${ }^{40}$

The possibility that interest costs may be lower, along with potential attendant benefits, may explain why a growing number of countries are issuing indexed debt. Canada and France have launched new programs over the past decade, and a number of other countries, some with high and variable levels of inflation, had established indexed debt programs much earlier. The United Kingdom implemented its program in 1981, and as of September 1999 indexed gilts represented about 22 percent of all outstanding U.K. government debt. ${ }^{41}$ By comparison, TIIS represented about 3 percent of all marketable U.S. government debt at that time. However, because of the size of the U.S. Treasury market, the dollar amount of TIIS outstanding is approaching the dollar-equivalent amount of outstanding indexed gilts.

\section{Market Activity in TIIS}

To date, the Treasury has issued six inflation-indexed securities-one five-year note, three ten-year notes, and two thirty-year bonds. Each issue has been reopened once, leaving its total size roughly between $\$ 14$ billion and $\$ 16$ billion. Currently, the Treasury issues only ten- and thirty-year TIIS, alternating between the two maturities at auctions in the first month of every quarter.

Activity in the secondary market for TIIS has remained moderate relative to comparable nominal issues. According to data for primary dealers collected by the Federal Reserve Bank of New York, daily trading volume in TIIS over the second quarter of 1999 averaged about 1.7 percent of TIIS outstanding, compared with about 5.0 percent for nominal Treasury notes and bonds. The more limited activity in TIIS may reflect the nature of these securities: They provide safe, stable long-run returns and may therefore appeal to investors who are less inclined to trade their holdings actively.

Other measures suggest that TIIS are somewhat less liquid than off-the-run nominal Treasury securities. ${ }^{42}$ Discussions with some primary dealers indicate that bid-offer spreads on TIIS, in terms of prices, are typically about $1.6 \notin$ to $6.3 \notin$ per $\$ 100$ face value.

40. Differences in duration and convexity between TIIS and nominal securities may also affect the yield spread.

41. Quarterly Gilts Review: 3rd Quarter 1999, United Kingdom Debt Management Office (October 1999).

42. No distinction is made between on-the-run and off-the-run TIIS because there are no large differences in liquidity between those securities, as is the case with nominal Treasury securities.
This spread is somewhat wider than bid-offer spreads for nominal Treasury securities, which are reportedly $1.6 \notin$ or less, but it is much narrower than bid-offer spreads for corporate bonds.

According to market participants, liquidity in the TIIS market is gradually improving. Aside from the pickup in volume during the market turmoil in the third quarter of 1998, the volume of TIIS transactions among primary dealers reported to the New York Reserve Bank has been about 26 percent higher in 1999 than in 1998, whereas the volume in nominal Treasury coupon securities has declined 12 percent. TIIS volume is concentrated around the auction cycle: Over the past four auctions, average daily volume during the four weeks after the announcement of an auction has been 92 percent higher than that during other weeks. Although the Chicago Board of Trade offers options and futures contracts on TIIS similar to those on other Treasury securities, market activity has been negligible.

\section{Yields on TIIS}

The first TIIS issued, a ten-year note, was auctioned on January 29, 1997, at a yield of 3.45 percent. Since then, the yield on the ten-year TIIS has generally risen to the current level above 4 percent (chart 9). Over that period, the yield on TIIS has been less volatile than that on the nominal ten-year security. On an average day, the ten-year TIIS yield changed less than $1 \frac{1 / 2}{2}$ basis points, compared with more than 4 basis points for the nominal security. In addition, the yield on the nominal security has moved in a much wider range of about $2 \frac{1 / 2}{2}$ percentage points, compared with about $3 / 4$ percentage point for the TIIS yield.

The spread between these yields-the inflation compensation on the ten-year nominal Treasury note-fell over 1997 and the first half of 1998, along with the actual rate of CPI inflation and a survey measure of long-run inflation expectations among professional forecasters. However, the decline in inflation compensation was more dramatic than that of the survey measure, suggesting that some of the narrowing of the yield spread may have been driven by a decline in the inflation risk premium.

Relative changes in yields may also be explained in part by differences in the liquidity of nominal securities and TIIS. In the fall of 1998, yields on nominal Treasury securities dropped sharply, pushing ten-year inflation compensation as low as 69 basis points. This dramatic narrowing of the yield spread, though it may have partially reflected a change in the 
outlook for inflation, was undoubtedly driven by a shift in investors' preferences toward more-liquid assets, particularly on-the-run nominal Treasury securities. Inflation compensation returned to higher levels in 1999 as the demand for liquidity lessened and inflation expectations rose.

TIIS yields also appear to be significantly influenced by supply. In particular, seven of the fourteen largest daily changes in the ten-year TIIS yield over the period shown in chart 9 took place immediately before or after TIIS auctions. The largest movements in the ten-year nominal yields, by contrast, were all in response to either macroeconomic news or the reallocation into safe and liquid assets during the fall of 1998.

\section{Reduction in the Supply of Nominal Treasury Debt}

In response to the budget surpluses of the past two years, the Treasury has decreased its securities issuance enough to shrink the amount of marketable debt outstanding. This development has several implications for the Treasury securities market.

\section{Developments in the Treasury Bill Market}

After decades of increases, marketable Treasury debt outstanding has decreased over the past two years. ${ }^{43}$ Because the issuance of Treasury bills has been cut more sharply than that of Treasury coupon securities, the decline has not been evenly spread across the maturity spectrum (table 4). From December 1996 to September 1999, total coupon securities outstanding declined about 7 percent whereas total bills outstanding decreased about 16 percent. In association with the downtrend in supply, the average daily trading volume in bills reported by primary dealers declined about 44 percent over the period (chart 10). In contrast, the average daily trading volume in nominal coupon securities reported by primary dealers in September 1999, though off its peak of fall 1998, was only about 2 percent below its level in December 1996.

The decline in the amount of bills outstanding may have weakened the connection between yields on bills and those on longer-term Treasury securities. ${ }^{44}$

43. However, total Treasury debt, which includes securities held in government accounts, has increased over the period.

44. Similar effects have been documented by Gregory R. Duffee, "Idiosyncratic Variation of Treasury Bill Yields," Journal of Finance, vol. 51 (June 1996), pp. 527-51.
9. Yields on nominal and indexed Treasury securities and indicators of inflation, 1997-99

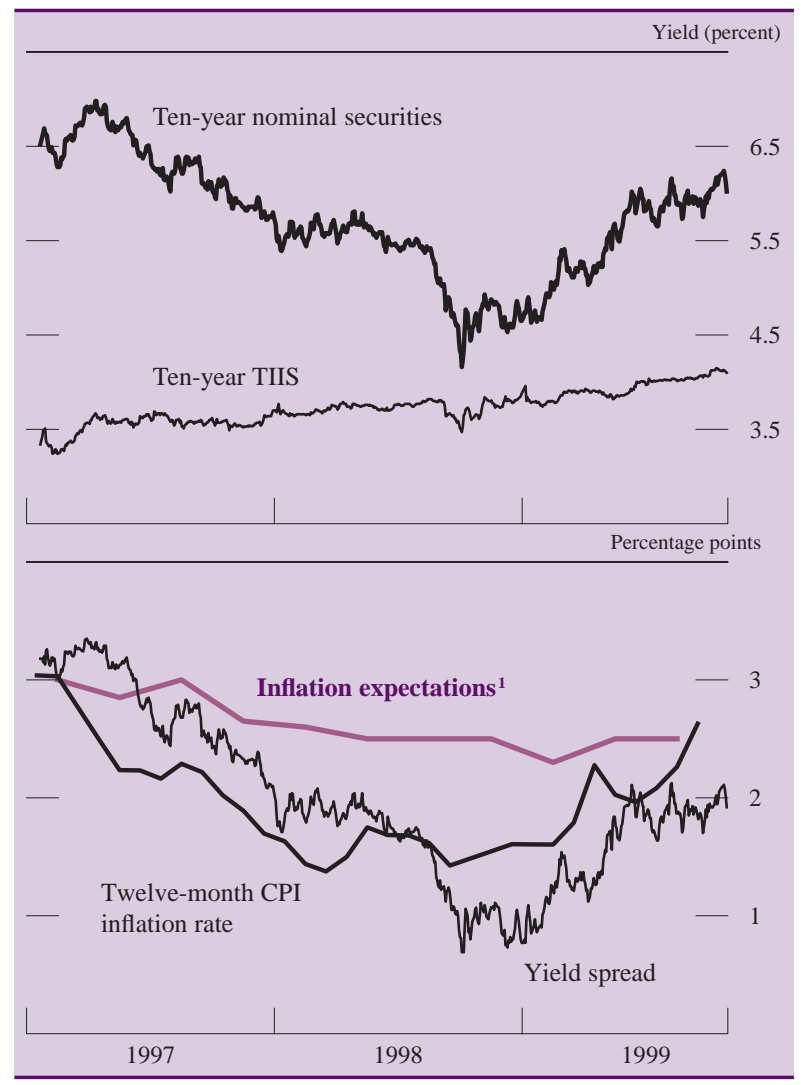

Note. Yield data are based on most recently issued securities and extend through October 1999; yield spread is yield on ten-year nominal securities less yield on ten-year TIIS. Expectations data and CPI data extend into the third quarter.

1. Median expectation of CPI inflation over the next ten years among professional forecasters surveyed by the Federal Reserve Bank of Philadelphia.

Source. Board of Governors of the Federal Reserve System, Federal Reserve Bank of New York, Bureau of Labor Statistics.

The spread between the six-month yield implied by a smoothed yield curve based on coupon securities and the yield on the six-month bill has increased over the past four years (chart 10). Although bills have typically commanded higher prices (lower yields) than coupon securities of similar maturities because of their greater liquidity, the recent increase in the spread is correlated with the decrease in the supply of bills and could suggest a scarcity premium on bills. ${ }^{45}$ Two conflicting effects may have been at play in the bill market: The reduction in issuance may have made bills less liquid, reducing their attractiveness relative to coupon securities; at the same time, the reduction in supply in the face of continuing strong

45. For insights into the relation between the liquidity of bills and coupon securities and their yields, see Yakov Amihud and Haim Mendelson, "Liquidity, Maturity, and the Yields on U.S. Treasury Securities," Journal of Finance, vol. 46 (September 1991), pp. 1411-25. 
4. Distribution of marketable Treasury debt outstanding, by maturity, 1994-99

Billions of dollars

\begin{tabular}{|c|c|c|c|c|c|}
\hline \multirow{3}{*}{ Year } & \multirow{3}{*}{ Total outstanding } & \multicolumn{4}{|c|}{ Maturity class } \\
\hline & & \multirow{2}{*}{ Bills } & \multicolumn{3}{|c|}{ Notes and bonds (remaining maturity) } \\
\hline & & & Less than 5 years & $5-10$ years & 10 years or more \\
\hline 1994 & 3,111 & 734 & 1,606 & 320 & 451 \\
\hline 1995 & 3,292 & 761 & 1,749 & 325 & 457 \\
\hline 1996 & 3,445 & 777 & 1,842 & 338 & 488 \\
\hline 1997 & 3,409 & 715 & 1,823 & 356 & 515 \\
\hline 1998 & 3,271 & 691 & 1,691 & 349 & 540 \\
\hline 1999 & 3,125 & 653 & 1,567 & 346 & 559 \\
\hline
\end{tabular}

Note. Data are for end of period; for 1999, data end on September 30. Excludes Treasury inflation-indexed securities (TIIS) and Federal Financing Bank series.

investor demand may have enhanced their relative attractiveness, pushing their prices up and their yields down.

10. Effect of the reduction in supply on the Treasury bill market, July 1994-September 1999

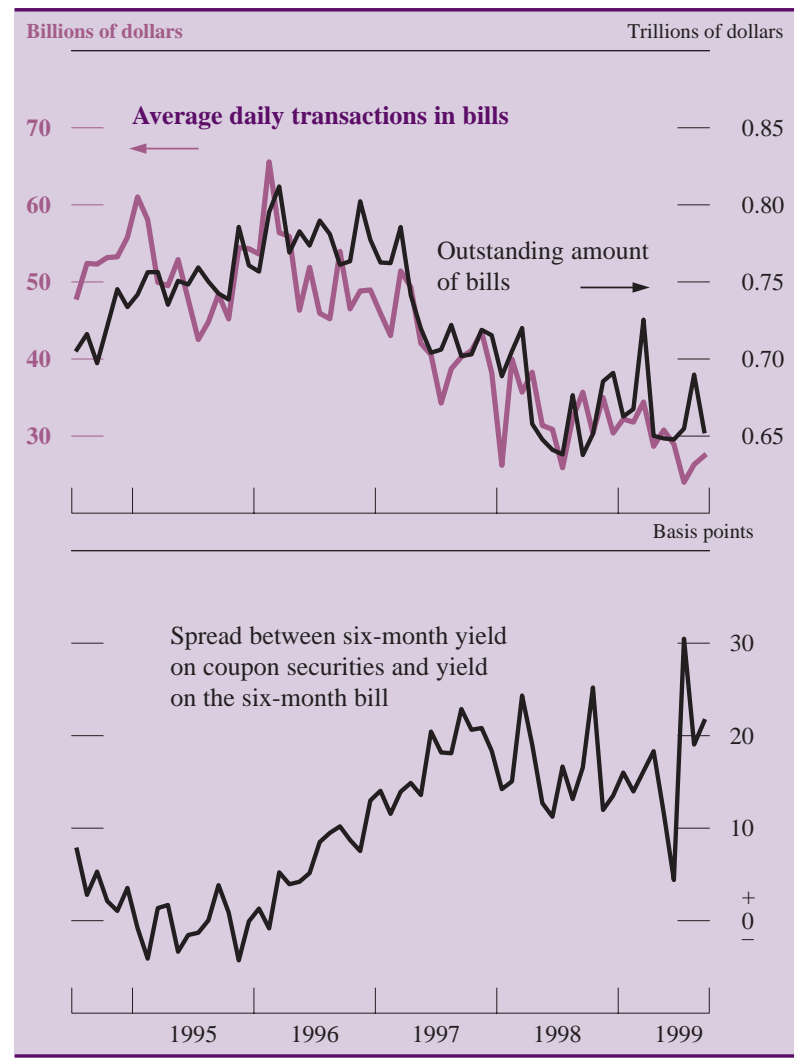

Note. The data are monthly. The six-month yield on coupon securities is the yield implied by a smoothed yield curve based on Treasury coupon securities with remaining maturities ranging from a few months to several years.

Source. Transactions, amounts reported by primary dealers to the Federal Reserve Bank of New York; outstanding amounts, Monthly Statement of the Public Debt of the United States; yield spread, authors' calculations.
Treasury Debt Buybacks

Faced with the prospect of continuing declines in the volume of debt outstanding, the Treasury has proposed a new tool for debt management. In August 1999, it published for comment a proposed rule under which it could repurchase its own securities in the market. The Treasury expects to be able by early 2000 to conduct buybacks should it decide to do so. The Treasury believes that the program would have three benefits. First, buybacks would allow it to maintain the large size of new issues, a feature thought to promote greater liquidity. (As noted earlier, the Treasury has also concentrated issuance in fewer maturities in order to preserve their size.) Second, it could use buybacks as a cash management tool, absorbing excess cash when tax revenues exceed immediate spending needs. And third, by concentrating the buybacks on longer-term securities, it would be able to halt the recent upcreep in the average maturity of the debt.

Under the current proposal, the buybacks would be implemented through "reverse auctions" in which the Treasury would announce the approximate total amount of the securities it wished to redeem and the particular securities that would be eligible. Bids would have to be submitted by or through primary dealers so that the Treasury could make use of the open market facility of the New York Reserve Bank. The total amount of bids accepted would not exceed, and could be less than, the announced amount of redemptions.

Some market observers believe that buybacks could initially reduce yields on the targeted securities relative to those on more liquid issues. They argue that investors, knowing that they will periodically have an opportunity to sell them back to the Treasury, 
may be less concerned about the lower liquidity of the targeted securities. However, some market participants, in their comments about the proposed rule, have expressed concern that removing a considerable portion of an individual Treasury issue through a buyback could decrease the liquidity of the securities from that issue that remain in the market.

Under current accounting rules for the federal budget, the buyback program could increase the reported level of federal spending in the short term. If the price at which a security is repurchased is above par, the premium would be counted as an interest expense in the year of the repurchase, although reported interest expenses in the future would decline.

Debt Issuance

by Government-Sponsored Enterprises

To fill the gap left by a dwindling supply of Treasury securities, two government-sponsored enterprises (GSEs), Fannie Mae and Freddie Mac, in 1998 introduced new series of debt securities that in some ways mimic Treasury securities: Fannie Mae "benchmark" and Freddie Mac "reference" notes and bonds. GSEs are federally chartered, private institutions; their debt securities are not backed by the full faith and credit of the United States. However, debt securities issued by GSEs are perceived as being quite safe and typically trade at yields only slightly above those on Treasury securities. ${ }^{46}$

By issuing securities regularly and in large volumes, these two GSEs appear to be structuring their issues so as to achieve the greater liquidity and benchmark status of Treasury securities, presumably to lower their financing costs. The two GSEs have also increased the predictability of the offerings by announcing issuance calendars in advance. Moreover, the new securities are designed to appeal to international investors, as they can be electronically transferred through international clearing organizations such as Euroclear and Cedel as well as through the NBES system.

As of early November 1999, outstanding amounts of benchmark and reference securities totaled more than $\$ 150$ billion, with maturities ranging from two to thirty years. ${ }^{47}$ That month, the two GSEs introduced benchmark and reference bills programs

46. Debt securities issued by GSEs are considered government securities for purposes of the Securities and Exchange Act of 1934. For details on legal provisions particular to GSE securities, see "Assessing the Public Costs and Benefits of Fannie Mae and Freddie Mac," Congressional Budget Office (May 1996), p. 10.

47. Excludes callable benchmark and reference notes. arranging for regular auctions of securities with maturities of less than one year.

Market participants characterize the liquidity of the most recently issued benchmark and reference notes as comparable to that of off-the-run Treasury securities. Indicative of their increased liquidity, benchmark and reference notes are actively used as collateral in the overnight repo market, although, reportedly, they are rarely used in term repo transactions. Benchmark and reference notes reportedly have begun to be used as substitutes for Treasury securities as instruments for hedging. Their yields have tracked yields on corporate debt and mortgage-backed securities more closely than have yields on Treasury securities, a characteristic traders have cited as an advantage for hedging purposes. The trading volume in GSE debt by primary dealers, however, amounts to only a fraction of their trading in Treasury securities.

\section{Trends in Market Structure}

The structure supporting the trading of Treasury securities has changed in several ways in recent years. Market participants have relied more heavily on private clearing arrangements since the Federal Reserve began assessing a fee on intraday credit. More recently, market participants have also increased their use of electronic trading systems.

\section{Use of Alternative Clearing Arrangements}

In April 1994, the Federal Reserve began to charge a fee on daylight overdrafts, initially at an annual rate of 24 basis points and raised to 36 basis points in 1995. Within six months after the fee was imposed, average daylight overdrafts fell 40 percent, from about $\$ 70$ billion to about $\$ 43$ billion. The decline was due partly to government securities dealers' decision to arrange repo transactions earlier in the day and to deliver securities used as collateral more quickly to cover overdrafts generated by the repayment of maturing repos. As a consequence, trading activity in the repo market became more concentrated early in the morning, spurring the trading desk at the Federal Reserve Bank of New York to enter the market earlier to conduct open market operations. The desk moved its intervention time from about 11:30 a.m. to 10:30 a.m. in January 1997 and to 9:30 a.m in April 1999. Another change in market practice has been the growing use of tri-party repos, in which both parties to the transaction use the same custodian bank, so that the securities used as collat- 
eral are shifted from one account to the other without leaving the custodian bank, thereby reducing daylight overdrafts at the Federal Reserve. Tri-party repos also facilitate the back-office handling of the transactions.

Market participants have also increased their use of netting arrangements, such as those offered by the Government Securities Clearing Corporation (GSCC). This industry service organization, established in 1986 and owned by market participants, provides centralized clearing and settlement services for outright and repo transactions in Treasury securities and some GSE-issued securities. GSCC establishes a single net position for each participant's daily trading activity in a given security by netting all cash and repo transactions and Treasury auction purchases. Netting may reduce the costs associated with securities transfers by reducing the number of transactions and lowering daylight overdraft charges. ${ }^{48}$

GSCC guarantees the settlement of all trades entered in its system by interposing itself between the original trading parties and becoming the legal counterparty for settlement purposes. Were a firm to become insolvent, GSCC would use the participant's clearing fund and margin deposits to liquidate the member's positions. If those deposits were insufficient to cover the liquidation of all positions, the remaining liabilities would be prorated among the participants who traded most recently with the failed firm. GSCC is used by primary dealers and other active market participants, who may value the confidentiality of brokered trades offered by the organization.

\section{Growth of Electronic Trading}

Participants in the Treasury market have typically arranged transactions by telephone. In recent years, however, advances in technology have enabled them to transact through electronic communication net-

48. Heidi Willman Richards, "Daylight Overdraft Fees and the Federal Reserve's Payment System Risk Policy," Federal Reserve Bulletin, vol. 81 (December 1995), pp. 1065-77. works. Electronic trading represents a small, though rapidly increasing, share of the aggregate trading volume of Treasury securities. Analysts estimate that the share of electronic trading in total trading activity in the Treasury market had risen from about half a percent on average in 1998 to about 2 percent to 4 percent by fall 1999, still well below the share of equity trading done on line (reported to be about 14 percent).

In November 1999, the Bond Market Association identified thirty-nine systems offering electronic transaction services in the U.S. market for government and private debt securities, up from twenty-six in 1998 and eleven in 1997.49 In addition, some interdealer brokers have introduced or plan to introduce electronic systems (primarily) for the Treasury market. These systems offer the same anonymity of the current interdealer broker system but could drive down interdealer broker fees, quicken execution, and streamline the relation between the "front office" and the "back office." The development of electronic interdealer brokerage is poised to boost the market share of electronic trading of Treasury securities.

\section{SUMMARY}

The market for Treasury securities is vast and serves important functions for numerous investors. The characteristics and behavior of the market are not static but instead evolve with the changing objectives and needs of both the Treasury and investors. This article has identified several important changes in recent years, including the introduction of indexed debt securities, a decline in budgetary needs, and changes in the way Treasury securities are traded. Although these and additional, unforeseen changes will continue to shape the Treasury market, the crucial role of Treasury securities in world financial markets is likely to remain unchanged.

49. eCommerce in the U.S. Fixed Income Markets: The 1999 Review of Electronic Transaction Systems, Bond Market Association (November 1999). 